\title{
Shear bond strength of resin composite to enamel treated with Er:Y AG laser and phosphoric acid
}

\author{
Resistência adesiva de resina composta ao esmalte condicionado com laser Er: \\ YAG e ácido fosfórico
}

\section{Nádia da Rocha SVIZERO \\ Renato Savi de CARVALHO}

Post-Graduate student (PhD) - Departament of Operative Dentistry - University of São Paulo, Bauru, School of Dentistry - Bauru - SP - Brazil

\section{Lucirene Aparecida DOMINGUES \\ Carolina Nunes PEGORARO}

Assistant Professor - Departament of Operative Dentistry - University of Sagrado Coração - Bauru - SP - Brazil

\section{Carlos Eduardo FRANCISCHONE}

Titular Professor - Departament of Operative Dentistry - University of Sagrado Coração, Bauru and University of São Paulo, School of Dentistry - Bauru - SP - Brazil

Máira Cristina Almeida ROCHA

Specialist in Operative Dentistry - University of Sagrado Coração - Bauru - SP - Brazil

\begin{abstract}
The purpose of this work was to evaluate the shear bond strength of resin composite to enamel treated with Er:YAG laser. It was used 33 human third molars. After the dental crowns cutting, the mesial and distal surfaces were embedded perpendicularly to the PVC cylinders long axis. Enamel was ground and the samples were randomly divided into 6 groups: G1- phosphoric acid (control), G2- Er:YAG laser (60mJ/10Hz), G3- Er:YAG (100mJ/10Hz), G4- Er:YAG (60mJ/10Hz + acid), G5- Er:YAG $(100 \mathrm{~mJ} / 10 \mathrm{~Hz}$ + acid), G6- Er:YAG $(80 \mathrm{~mJ} / 2 \mathrm{~Hz})$. In all groups, Single Bond was used and resin composite cylinders (Z100) were prepared. The samples were stored in distilled water at $37^{\circ} \mathrm{C}$ for 24 hours and submitted to shearing test. G1 presented bond strength values significantly higher than G2, G3 and G6. The groups irradiated only with Er:YAG laser, in different intensities and frequencies, were equivalent as for the bond strength values. The groups treated with laser + acid presented strength values statistically equal to those of the control group. The enamel treatment with phosphoric acid, or its association with laser, is important to obtain good bond. The use of Er: YAG laser alone is not recommended, considering the conditions tested in this study.
\end{abstract}

\section{UNITERMS}

Er:YAG laser; enamel; shear bond strength; phosphoric acid; resin composite.

\section{INTRODUCTION}

Laser irradiation was initially used in dentistry by Ralph Stern and Reidar Sognnaes ${ }^{16}$, when they vaporized dental enamel with ruby laser, resulting in craters on the surface where the enamel was fused, causing a vitrified aspect. Such observations indicated laser as a probable substitute for dental burs, which was impossible that time due to the obtained results and the lack of knowledge on possible damages to the pulp.
With the evolution of apparatus and researches, other types of laser appeared, more adequate to irradiation of each tissue and to the effect desired. Several factors influenced the interaction laser-tissue, and each clinical situation requires a specific type of irradiation. Advances in researches and the appearing of other types of laser have permitted this technology to be applied in several dentistry specialties. In restorative procedures, laser would act as a conditioning agent 
previous to adhesive restorations in association or replacement to the method proposed by Buonocore ${ }^{5}$ that is, conditioning enamel with phosphoric acid, which is used nowadays.

Eduardo ${ }^{8}$ compared the resistance to shearing of composite resin to dental enamel conditioned with Er:YAG laser or phosphoric acid, and concluded that the irradiation did not provide satisfactory adhesion. Later, Groth ${ }^{12}$ performed tension tests to evaluate the retention obtained between conditioned enamel and composite resin, comparing groups treated with phosphoric acid at 37\%, Er:YAG laser and Er:YAG/ acid association. The best results were presented by double conditioning, followed by the acid conditioning; however, there was no statistical difference among them. Concerning dentin conditioning, Visuri et al. ${ }^{18}$ found higher values of adhesive resistance in surfaces irradiated with Er: YAG compared to those treated with burs. On the other hand, Sassi et al..$^{15}$ and Bertrand et al. ${ }^{3}$ observed more homogeneous hybrid layers and more uniform "tags" in samples conditioned with acid, while in dentin treated with laser, associated or not with acid conditioning, the hybrid layer was thinner with "tags" absence or narrowing.

Due to controversial results on the benefits that laser can bring to the adhesive techniques and, being this a new technology used in dentistry, new studies and researches are necessary to further exploration of such resource, proving and optimizing the results already accomplished.

This study proposed to evaluate the shear bond strength of resin composite to enamel treated with Er:YAG laser, in different energy parameters, phosphoric acid and the association of both.

\section{Material AND MEthods}

Thirty-three human newly extracted third molars stored in physiologic solution, were used. The roots were removed and the crowns were divided in half in vestibular-lingual direction, providing two proof bodies from each tooth. The coronary portions were embedded in PVC cylindrical rings ( $3 / 4$ inches diameter and $1.5 \mathrm{~cm}$ high), containing a special hybrid resin (polyester resin) which spends little polymerization heat. The teeth were embedded with mesial and distal surfaces perpendicular to the cylinder long axis. After the resin final polymerization, the dental enamel of each sample was ground (Figure 1) with \#600-grit silicon carbide (SiC) paper (Buehler Ltd., Lake Bluff, IL, USA) and then, prepared to receive the bonding of resin composite cylinders on which the shearing force will be applied.

Six groups with 11 specimens each were randomly divided and received one of the following treatments:

Group 1: the enamel surface central region was conditioned with $37 \%$ phosphoric acid for 30 seconds, water rinsed for 1 minute and dried by applying tissue paper. Soon after the acid etching, the Single Bond adhesive system (3M ESPE, St Paul, MN, USA) was applied on the surface and photopolymerized according to the manufacturer instructions.

Group 2: the enamel surface central region was irradiated with Er:YAG laser K.E.Y. II (Kavo Dental

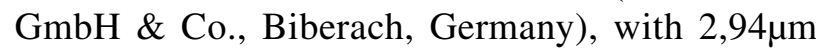
wavelength, with an $60 \mathrm{~mJ}$ pulse energy and a $10 \mathrm{~Hz}$ repetition rate (frequency), at a distance of $12 \mathrm{~mm}$ from the tooth surface to the apparatus lens (Figure 2). This distance, used in all groups receiving irradiation, was controlled by an adapted and fixed endodontic KFile (Figure 3). Following, the adhesive Single Bond (3M ESPE) was applied according to the manufacturer instructions.

Group 3: the enamel surface central region was irradiated with Er:YAG laser, $100 \mathrm{~mJ}$ and $10 \mathrm{~Hz}$, at a distance of $12 \mathrm{~mm}$ from the tooth surface to the apparatus lens. Following, the adhesive Single Bond (3M ESPE) was applied and photopolymerized according to the manufacturer instructions.

Group 4: the enamel surface central region was irradiated with Er:YAG laser, $60 \mathrm{~mJ}$ and $10 \mathrm{~Hz}$, at a

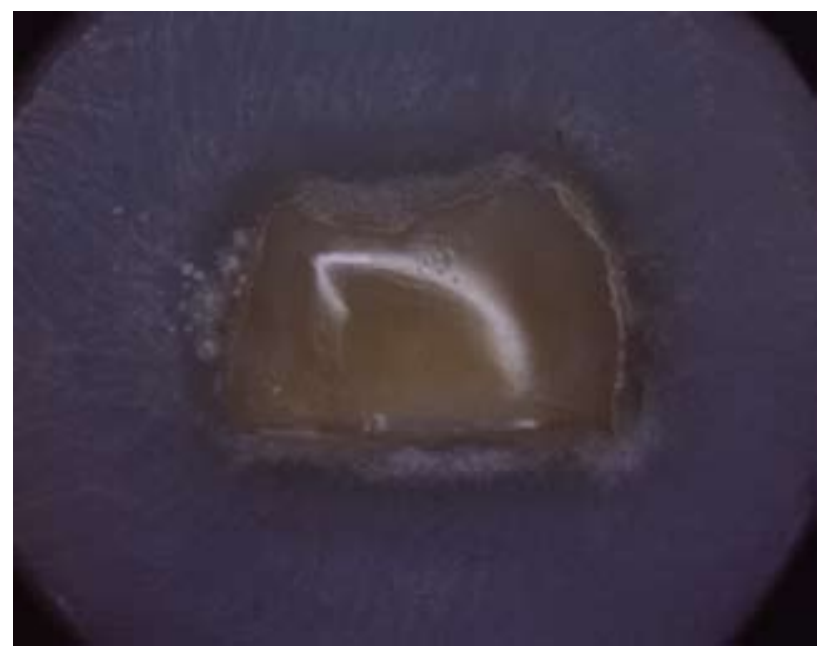

FIGURE 1 - Flatted enamel surface after \#600-grit silicon carbide paper 


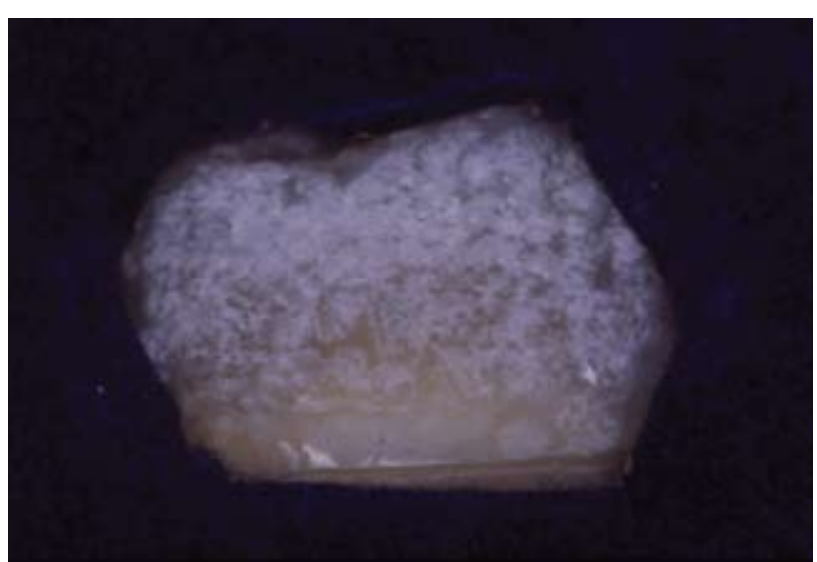

FIGURE 2 - Aspect of the enamel soon after Er:YAG laser irradiation.

distance of $12 \mathrm{~mm}$ from the tooth surface to the apparatus lens. After the enamel irradiation, the region was conditioned with $37 \%$ phosphoric acid for 30 seconds and water rinsed for 1 minute. Soon after the acid conditioning, the adhesive agent Single Bond (3M ESPE) was applied on the surface and photopolymerized according to the manufacturer instructions.

Group 5: the enamel surface central region was irradiated with Er:YAG laser, $100 \mathrm{~mJ}$ and $10 \mathrm{~Hz}$, at a distance of $12 \mathrm{~mm}$ from the tooth surface to the apparatus lens. Following, the region was conditioned with $37 \%$ phosphoric acid for 30 seconds and water rinsed for 1 minute. Soon after the acid conditioning, the dental adhesive Single Bond (3M ESPE) was applied on the surface and photopolymerized according to the manufacturer instructions.

Group 6: the enamel surface central region was irradiated with Er:YAG laser, $80 \mathrm{~mJ}$ and $2 \mathrm{~Hz}$, at a distance of $12 \mathrm{~mm}$ from the tooth surface to the apparatus lens. Following, the dental adhesive Single Bond (3M ESPE) was applied on the surface and photopolymerized according to the manufacturer instructions.

It was not conducted a Group combining $80 \mathrm{~mJ} / 2$ $\mathrm{Hz}$ with $37 \%$ phosphoric acid supported in a previous research ${ }^{4}$ that which these conditions were similar.

In order to restrict and standardize the enamel area to be exposed to the resin composite, a piece of insulating tape with a 3-mm-diameter central hole was attached to specimen surface (Figure 4).

From a teflon mold, resin composite cylinders with $3 \mathrm{~mm}$ of diameter and $6 \mathrm{~mm}$ high were built. It was used the resin composite Z100 (3M ESPE, St Paul, $\mathrm{MN}$, USA), A1, in three increments, polymerized for 40 seconds each by $600 \mathrm{~mW} / \mathrm{cm} 2$ (Optilux-Demetron Research Corporation, Danbury, CT), which was also

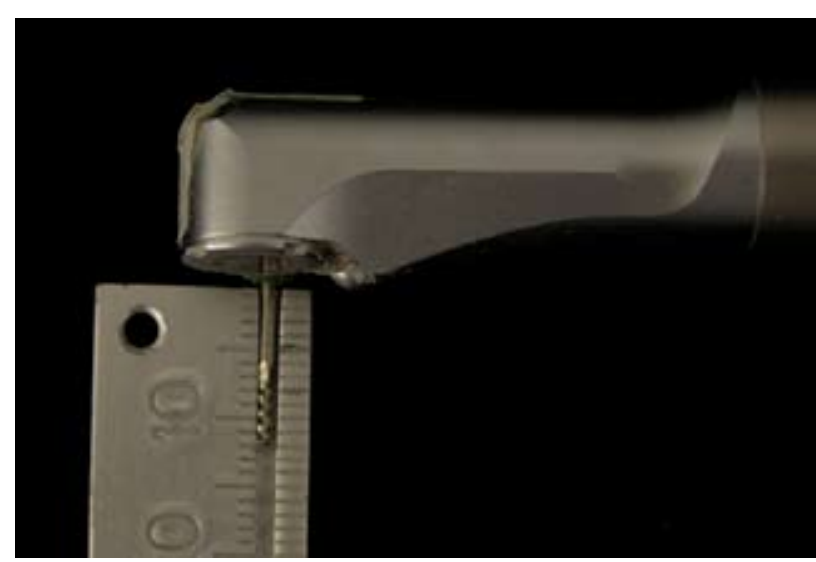

FIGURE 3 - Adapted endodontic K-File fixed in hand piece.

used in all previous procedures requiring photopolymerization. The tip was positioned touching the teflon mold. Fifteen minutes after polymerizing the last increment of the resin composite, all samples were stored in distilled water in oven at $370 \mathrm{C}$ for 24 hours.

After the storage time, the samples were submitted to shear bond strength test in a universal test machine Kratos (Dinamômetro Kratos Ltda. São Paulo/Brasil), with load cell no 2 (up to $100 \mathrm{Kg}$ ) at a speed of 0.5 $\mathrm{mm} / \mathrm{min}$. Axial loading was applied through a beveled metallic pole with an active tip $0.5 \mathrm{~mm}$ thick, placed in a way to stay on the adhesion area, the nearest possible from the substrate, however, without touching it (Figure 5).

After the fracture at the resin composite/ enamel interface, the values obtained from the test machine

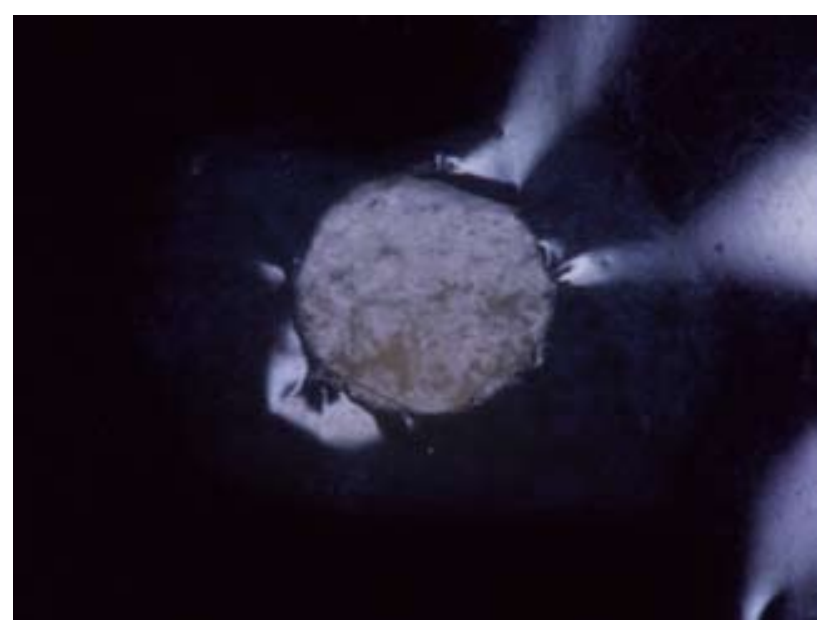

FIGURE 4 - Insulating tape limiting the bonding area. 


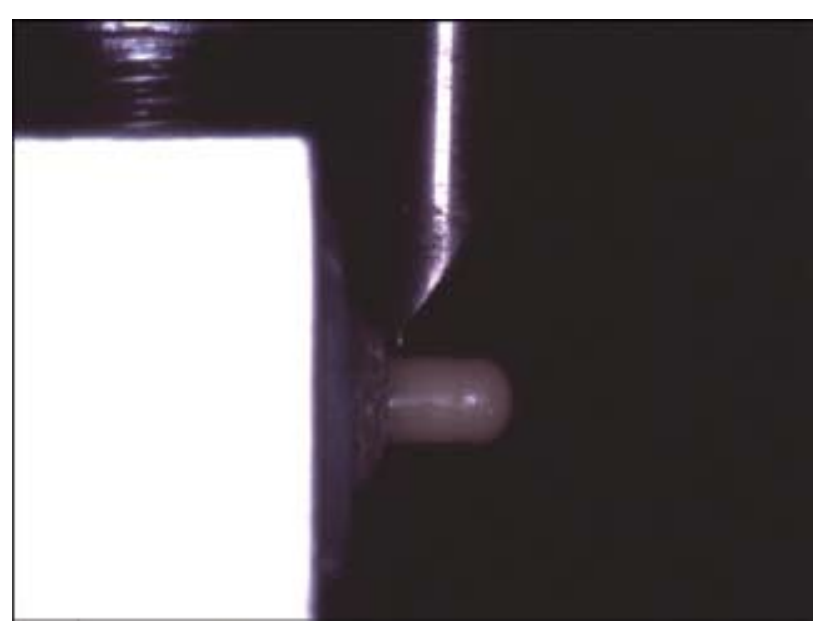

FIGURE 5 - Axial force being applied on the bonding area during the shearing test.

were converted into $\mathrm{Kg} / \mathrm{cm}^{2}$, then into $\mathrm{MPa}$, and submitted to statistical analysis (ANOVA 5\% and Tukey's test).

\section{Results}

Each group mean values and standard deviation are shown on Table 1.

Through individual comparisons based on Tukey's test, it was verified that the group where the enamel was treated with phosphoric acid only, presented bond strength values significantly higher than groups treated with $60 \mathrm{~mJ}, 100 \mathrm{~mJ}$ and $80 \mathrm{~mJ} / 2 \mathrm{~Hz}$. The group treated with $100 \mathrm{~mJ}+$ acid showed higher bond strength values than groups irradiated with $60 \mathrm{~mJ}$ and $100 \mathrm{~mJ}$. The treatment $100 \mathrm{~mJ}+$ acid presented no statistical

Table 1: Shear bond strength data and standard deviation of the groups (MPa)

\begin{tabular}{ccc}
\hline Groups & Mean* $^{\star}$ & $\begin{array}{c}\text { Standard } \\
\text { Deviation }\end{array}$ \\
\hline acid & $33.8 \mathrm{a}$ & 10.0 \\
$100 \mathrm{~mJ}+$ acid & $32.0 \mathrm{ab}$ & 9.4 \\
$60 \mathrm{~mJ}+$ acid & $29.9 \mathrm{abc}$ & 11.5 \\
$80 \mathrm{~mJ} / 2 \mathrm{~Hz}$ & $22.7 \mathrm{bc}$ & 6.7 \\
$100 \mathrm{~mJ}$ & $20.6 \mathrm{c}$ & 6.8 \\
$60 \mathrm{~mJ}$ & $20.2 \mathrm{c}$ & 5.1 \\
\hline
\end{tabular}

* Different letters indicate statistically significant difference (ANOVA 5\% and Tukey). difference from the group treated with $80 \mathrm{~mJ} / 2 \mathrm{~Hz}$. The group $60 \mathrm{~mJ}+$ acid was not statistically different from the others, showing bond strength values intermediate among the groups treated with acid (irradiated with laser or not), and only irradiated with laser.

\section{Discussion}

dental enamel irradiation with different types of laser causes alteration in this tissue superficial morphology ${ }^{1,8,9,12,14}$, which made some authors think that such procedure would be an alternative for the phosphoric acid to etch the enamel and obtain retention for the adhesive systems.

According to the results obtained in this work, the control group (acid etching) presented the highest bond strength values (Table 1), differing statistically from all the groups where acid was not used. This means that phosphoric acid is essential for enamel adhesion and could not be replaced for single irradiation with Er:YAG, with the intensities and frequencies used in this study.

Similar results were obtained by Eduardo et al. ${ }^{8}$, who observed that microporosities formed by Er:YAG in the enamel, with irradiation of $140 \mathrm{~mJ}$ and $300 \mathrm{~mJ}$, offered shear bond strength values lower than those obtained with acid alone. Groth et al. ${ }^{11}$ and Domingues et al. ${ }^{7}$ drew the same conclusions, comparing other irradiation intensities in association with acid, as well Fuhrmann ${ }^{10}$ who observed higher bond strength of resin composite to enamel treated with acid conditioning, when compared to those irradiated with laser $\mathrm{CO}_{2}$ and $\mathrm{Nd}$ :YAG.

Comparing the three irradiation conditions used $(60 \mathrm{~mJ} / 10 \mathrm{~Hz}, 100 \mathrm{~mJ} / 10 \mathrm{~Hz}$ and $80 \mathrm{~mJ} / 2 \mathrm{~Hz})$, it is possible to state that they produced the same pattern of conditioning in the enamel, since they presented no significant differences among them (Table 1), thus, they are equivalent as for the promotion of resistance to shearing efforts. Other works which compared different intensities and frequencies of enamel irradiation with Er:YAG, did not find any differences in adhesive pattern, either ${ }^{8,11,12}$.

Such information did not coincide with the results obtained by $\mathrm{Bispo}^{4}$, who testing the tensile strength, found out that the enamel irradiated with Er:YAG at $80 \mathrm{~mJ}$ and $2 \mathrm{~Hz}$ presented values similar to those with only phosphoric acid conditioning. This irradiation parameter $(80 \mathrm{~mJ} / 2 \mathrm{~Hz})$ showed to be superior than that in the other groups which were only irradiated. Such intensity and frequency represented one of the groups 
evaluated in this work, which showed similar results to the other parameters assessed and, statistically, inferior to the adhesion provided with phosphoric acid alone.

In spite of not promoting retention comparable to acid, the physical-chemical alterations caused by irradiation in the enamel did not damage the posterior action of the acid on the creation of retention. The groups that were irradiated and had this irradiation combined with acid application presented shear bond strength values statistically equal to the groups where acid was applied on non-irradiated enamel (Table 1). Trajtenberg ${ }^{17}$ observed higher adhesion when enamel and dentin were irradiated with laser Er:YAG previously to acid conditioning, compared to those prepared only with carbide bur + acid. Conversely, De Munck et al. ${ }^{6}$ observed lower microtensile bond strength values on cavities prepared with laser when compared to those prepared with diamond burs. Using micro-tomographic analyses, Groth ${ }^{13}$ noticed that irradiation with laser Er:YAG, previous to acid conditioning, despite revealing a slight reduction in mineral concentration, suggests an increase in porosity, permitting higher acid penetration as well increase in the conditioning depth. This can explain the good results obtained with laser/acid association in the present work. Increase in the surface free energy and more effective removal of the "smear layer" may also be factors of contribution to these results, as showed by Armengol et al. ${ }^{2}$ and Trajtenberg ${ }^{17}$, who, respectively, compared surfaces treated with laser + acid and only acid or laser. Thus, using laser to prepare and to etch the cavo-surface margin is a safe procedure, since it does not interfere negatively in the restorations final quality, which was also observed by Groth ${ }^{12}$ and Domingues et al. ${ }^{7}$.

In spite of the present work as well the ones above mentioned having been developed in laboratory, it can be found clinical reports in textbooks ${ }^{19}$ where enamel irradiation with laser is equal to acid in promoting retention.

\section{Conclusion}

From the statistical results obtained in this study, it can be concluded that the groups irradiated only with Er:YAG, in different parameters of intensity and frequency, were similar as for the shear bond strength. The enamel acid conditioning as unique superficial treatment or combined with irradiation of Er:YAG at 60 or $100 \mathrm{~mJ}$, offered the best bond strength results. The enamel irradiation with Er:YAG laser, previously to acid conditioning, does not interfere in its action. This way, erbium laser behavior still deserves longterm clinical evaluations, for being a relatively new technology for cavity preparation.

\begin{abstract}
Resumo
Objetivou-se avaliar a resistência adesiva da resina composta ao esmalte condicionado com Er:YAG laser, através do teste de cisalhamento. Foram utilizados 33 terceiros molares humanos. Após o seccionamento das coroas dentárias, as faces mesial e distal foram incluídas perpendiculares ao longo eixo de cilindros de PVC. O esmalte foi planificado com lixa 600 e os espécimes aleatoriamente divididos em 6 grupos: G1- ácido fosfórico (controle), G2- Er:YAG laser (60mJ/10Hz), G3- Er:YAG (100mJ/10Hz), G4- Er:YAG (60mJ/10Hz + ácido), G5- Er:YAG (100mJ/ 10Hz + ácido), G6Er:YAG $(80 \mathrm{~mJ} / 2 \mathrm{~Hz})$. Em todos os grupos, o sistema adesivo Single Bond foi aplicado e os cilindros de resina composta (Z100) confeccionados. Os espécimes foram armazenados em água destilada a $37^{\circ} \mathrm{C}$ por $24 \mathrm{~h}$ e submetidos ao teste de cisalhamento. O G1 apresentou valores de resistência adesiva significantemente superiores aos grupos G2, G3 e G6. Os grupos irradiados apenas com Er: YAG laser, nas diferentes intensidades e frequiências, equivaleram-se quanto aos valores de resistência adesiva. Os grupos tratados com laser + ácido apresentaram valores de resistência estatisticamente iguais ao grupo controle. O tratamento do esmalte com ácido fosfórico, ou a sua associação com laser, é importante para a obtenção de uma boa adesão. A utilização somente do Er: YAG laser não é recomendada, considerando-se as condições testadas neste estudo.
\end{abstract}

\title{
UNITERMOS
}

Laser Er:YAG; esmalte; resistência ao cisalhamento; ácido fosfórico; resina composta.

\section{Acknowledgement}

The authors gratefully acknowledge FAPESP (process no 98/05059-1) for financial support. 


\section{References}

1. Arcoria CJ, Lippas MG, Vitasek BA. Enamel surface roughness after laser ablation and acid-etching. J Oral Rehab 1993;20:213-24.

2. Armengol V, Laboux O, Weiss P, Jean A, Hamel H. Effects of Er:YAG and $\mathrm{Nd}$ :YAP laser irradiation on the surface roughness and free surface energy of enamel and dentin: an in vitro study. Oper Dent 2003;28:67-74.

3. Bertrand MF, Hessleyer D, Muller-Bolla M, Nammour S, Rocca JP. Scanning electron microscopic evaluation of resin-dentin interface after Er:YAG laser preparation. Lasers Surg Med 2004;35:51-7.

4. Bispo LB. Condicionamento do esmalte com Er:YAG laser e ácido fosfórico: resistência à tração e microscopia eletrônica de varredura. São Paulo; 2000. [Dissertação de Mestrado - Faculdade de Odontologia da Universidade de São Paulo]

5. Buonocore MG. A simple method of increasing the adhesion of acrylic filling materials to enamel surfaces. J Dent Res 1955;34:849-53.

6. De Munck J, Van Meerbeek B, Yudhira R, Lambrechts P, Vanherle G. Micro-tensile bond strength of two adhesives to Erbium:YAG-lased vs. bur-cut enamel and dentin. Eur J Oral Sci 2002;110:322-29.

7. Domingues LA, Veronezi MC, Pegoraro CN, Legramandi DB, Francischone CE, Ramos ACB. Shear bond strength of composite resin to enamel condictioned Er: YAG laser [abstract n.2300]. J Dent Res 1999;78 (special Issue):393.

8. Eduardo CP. Micromorphological evaluation of enamel surface and the shear bond strength of a composite resin after Er:YAG laser irradiation. An "in vitro" study. In: Anais do $5^{\text {th }}$ Congress of the International Society for lasers in Dentistry; 1996; Jerusalem. p.19.

9. Eguro T, Maeda T, Ogawa M, Nishimura Y, Otsuki M, Tanaka H. Human enamel changes by the Er:YAG laser irradiation [abstract $\mathrm{n}$. 3141]. J Dent Res 1999;78 (special Issue): 498.

10. Fuhrmann R, Gutknecht N, Magunski A, Lampert F, Diedrich P. Conditioning of enamel with Nd:YAG and $\mathrm{CO} 2$ dental laser systems and with phosphoric acid. An in-vitro comparison of the tensile bond strength and the morphology of the enamel surface. J Orofac Orthop 2001;62:375-86.

11. Groth EB. The pre-treatment of enamel surface "in vitro" with Er:YAG laser for bonding composite resin. In: Anais do $5^{\text {th }}$ Congress of the International Society for lasers in Dentistry; 1996; Jerusalem. p.5-9,12.
12. Groth EB. Estudo comparativo do condicionamento do esmalte dental com Er:YAG laser e ácido fosfórico: análise morfológica e resistência à tração. São Paulo; 1997. [Tese de Doutorado] São Pailo: Faculdade de Odontologia da Universidade de São Paulo; 1997.

13. Groth EB, Mercer CE, Anderson P. Microtomographic analysis of subsurface enamel and dentine following Er:YAG laser and acid etching. Eur J Prosthodont Restor Dent 2001;9:73-9.

14. Hess JA. Scanning Electron Microscopic Study of Laser- Induced morphologic changes of a coated enamel surface. Laser Surg Med 1990; 10:458-62.

15. Sassi JF, Chimello DT, Borsatto MC, Corona SA, Pecora JD, PalmaDibb RG. Comparative study of the dentin/adhesive systems interface after treatment with Er:YAG laser and acid etching using scanning electron microscope. Lasers Surg Med 2004;34:385-90.

16. Stern RH, Sognnaes RF. Laser effect on dental hard tissues. A preliminary report. J South Calif Dent Assoc 1965;33:17-9.

17. Trajtenberg CP, Pereira PN, Powers JM. Resin bond strength and micromorphology of human teeth prepared with an Erbium:YAG laser Am J Dent 2004;17:331-6.

18. Visuri SR, Gilbert JL, Wright DD, Wigdor HA, Walsh JT Jr. Shear strength of composite bonded to Er:YAG laser-prepared dentin. J Dent Res 1996;75:599-605.

19. Walsh LJ. Split-mouth study of sealant retention with carbon dioxide laser versus acid etch conditioning. Aust Dent J 1996;41:124-27.

Recebido em 27/10/06 Aprovado em 05/10/07

Correspondence to: Prof. Dra. Lucirene Aparecida Domingues Universidade do Sagrado Coração Rua: Nicolau de Assis 4-49, Ap. 43 - Jd Panorama 17011-102 - Bauru - SP - Brazil e-mail: lucidom@zipmail.com.br 